\title{
The Transparency Principle in Realize Good Corporate Governance: Limited Company
}

\author{
Lisma Lumentut, Badriyah Rifai, Sukarno Aburaera, Juajir Sumardi \\ Graduate School, Hasanuddin University, South Sulawesi - Indonesia
}

\begin{abstract}
The transparency principle of limited company is required to increase the confidence, support, and participation of stakeholders or all parties concerned with the company. Function and authority of company organ needs to be done in a transparent manner to achieve Good Corporate Governance. This study was a sociojuridical research, in the field of civil law, particularly with regard to corporate law. The populations of this study are directors, shareholders, commissioner, consumers in the form of a limited company in South Sulawesi province. The samples are part of population and it determined by purposive technique. The results shows that basic concepts of transparency were an attitude or action of the company to disclose entire business and information material about the effects that can affect the decisions of investors or other stakeholders. Information disclosure is determined by three factors: clear, accurate, and timely. These third determines the quality of information presented by the company. The level of transparency tends to be higher in term of nonfinancial information, but instead tend to be closed when it comes to financial information, particularly on the closed company or not a public company.
\end{abstract}

Keywords:- Business Law, Good Corporate Governance, Limited Company, Transparency

\section{INTRODUCTION}

Limited company as one of the pillars of the national economy development, therefore it needs to be managed well to encourage economic development and improving the welfare of society at large. In this regard, the business actors, both private and government as investor be part of the implementation of the national economy.Consider the importance of the role of enterprises in supporting the success of the national economic development, then the companies both private and government must be managed in accordance with the principles of Good Corporate Governance. Under the provisions of Article 15 letter $a$ of Act No. 25 of 2007 on Investment, stated that every investor is obliged to apply the principles of Good Corporate Governance. The investor in question is individual or business entity that invests capital, which can be either domestic- or foreign investors. ${ }^{1}$ This shows that every investor, especially for limited companies isobliged to apply the principles of Good Corporate Governance(GCG).Based on regulation of Bank Indonesia No. 8/14/PBI/2006, the principles of Good Corporate Governanceare the principles of transparency, accountability, responsibility, and fairness. The principles are basically a concept concerning the corporate structure, division of duties, division of authority, and division of responsibility of each element of the company structure. The fourth principle of Good Corporate Governanceshould be implemented simultaneously in order that Good Corporate Governancecan be achieved. ${ }^{2}$ The principle of regulation in Bank Indonesia No. 8/14/PBI/ 2006, basically in accordance with the principles set by the Organization for Economic Co-operation and Development (OECD), include the principles of transparency, accountability, responsibility and fairness. ${ }^{3}$ However, when referring to the provisions of Public Information Disclosure Acts, in addition to the four principles as defined by the Organization for Economic Cooperation and Development (OECD), there is still one another principle, namely the principle of independence. The provision above indicates that any investment activity should be carried out based on the principle of openness (transparency). In this regard, the investors may be as individuals or business entities that perform investment activities. ${ }^{4}$ Thus, a limited company as one form of business entity conducting investment activities, it also shall apply the principles of transparency, especially when the limited company as open corporate. The obligation for every investment corporate to apply the principles of Good Corporate Governance, suggesting that the principle of transparency (full disclosure) as one of the principles of Good

\footnotetext{
${ }^{1}$ See, Article 1 figure 4 of Act No.25 of 2007 on Investment.

${ }^{2}$ Tavinayati and Yulia Qamariyanti. 2009.Hukum Pasar Modal Indonesia, Jakarta: Sinar Grafika, p 56

${ }^{3}$ Luhgiatno.2008. Mencegah Tindakan Manajemen Laba dengan MekanismeCorporateGovernance, Jurnal Fokus Ekonomi, $3(2): 32-43$

${ }^{4}$ Muhammad Miqdad, 2012. Praktik Tatakelola Perusahaan (Corporate Governance). Jurnal Manajemen dan Kewirausahaan, 14(2): 9.
} 
Corporate Governance, it must be applied by the company.Some studies that have been done previously by several researchers, it also shows that governance in state- and regional-owned enterprises, tend to be lower than in the private sector, ${ }^{5}$ especially from the aspect of transparency or information disclosure. ${ }^{6}$ It is also revealed in a discussion held by the Financial and Development Supervisory Agency on August 26, 2014 in Riau. According to Hardy Jamaladin, ACFE Chairman Riau Region, that the Roundtable Discussionwas conducted due to not managed well the aspect of management of SOEs/ROEs, so it is still labeled corrupt or bad corporate governance. $^{7}$

Definitively, Good Corporate Governance represent a system to regulate and control the enterprise and create value added for all stakeholders, both primary stakeholders (investors, employees and managers, suppliers, business partners and the community) and secondary stakeholders. ${ }^{8}$ Good Corporate Governance(GCG) is a process used by the organs of the company to determine the policy and to increase the success of business and corporate accountability, so it can increase the added value for shareholders in the longterm, taking into account the interests of stakeholders by budget basis of the company and the legislation in force.In order to exercise all rights and obligations, the limited company creates organ with their functions and authority. The implementation of function and authority of company organ needs to be done in a transparent manner to achieve Good Corporate Governance. Low levels of transparency or not the application of the principle of transparency in the management of company as revealed in the index of business environment transparency that released by the Political and Economic Risk Consultancy (PERC), regarded due to lack of understand the nature of the management of a limited company in responsible manner.

Based on this, the research is intended to see and study how the implementation of the principle of transiency in realizes Good Corporate Governance in limited companies, both private and state enterprises. A research is carried out simultaneously to both types of companies, also allows for comparisons regarding the implementation of the principles of Good Corporate Governancebetween the private and State-Owned Enterprises (SOEs).

\section{METHOD OF THE RESEARCH}

The study was conducted in South Sulawesi province, Indonesia. This study was a socio-juridical research, in the field of civil law, particularly with regard to corporate law. The populations of this study are directors, shareholders, commissioner, consumers in the form of a limited company in South Sulawesi province. The samples are part of population and it determined by purposive technique.

\section{Basic Concept of Transparency in Realize Good Corporate Governanceon Limited Company}

The term "transparency" is derived from the word "transparent,"it means a state that is not closed, or not be kept secret so that everyone has a right to know certain information. The term is derived from English transparency that is clear, obvious, clear, easy to understand, there is no mistake, there is no doubt or hesitation.

Transparency refers to actions that enable a problem becomes clear, easy to understand, and no doubt its truth. Transparency can be defined as a condition where all information required available and can be provided or obtained by a related party or the wider community. Open/transparent attitude is attitude to be willing to tell and willing to accept the knowledge or information of the other party. The implementation of the principle of transparency in the limited company is required to increase the confidence, support, and participation of stakeholders or all parties concerned with the company. ${ }^{9}$ The transparent company will easily accept the change and allow progress. The management can learn to accept new things that are useful for the progress of the company. Instead, a closed/not transparent company will be difficult to develop and adapt to progress. The principle of transparency relates to the quality of information presented by the company. Investors' confidence will depend largely on the quality of information submitted by the company. Therefore, companies are required to provide information that is clear, accurate, and timely. The thing third is the basis for determining the quality of the information presented by the company.Clear information can mean that the information presented by the company is easy to understand and does not raise doubts for the recipient of information. Furthermore, accurate means that the information is correct and right on target, while the timely means that the information is not fast nor slow. Information delivered prematurely and unclear its certainty would not be maximal, as well as if the information is delayed, new information came later after the decision is taken, and such information also would not be maximal.Other thing that also determines the quality of information is the similarity of information for all

\footnotetext{
${ }^{5} \mathrm{KPK}$, Studi Implementasi Good Corporate Governance di Sektor Swasta, BUMN dan BUMD. KPK, Direktorat Penelitian dan Pengembangan, Jakarta, 2007. Pages, 16-17

${ }^{6}$ Erwin Fajrin Hadat, Informasi: Kebutuhan yang Terabaikan, Buletin BUMN, 65(4): 28. 2007.

${ }^{7}$ BPKP, Peran SPI BUMN/BUMD Dalam Implementasi Good Corporate Governance dan Pencegahan Fraud.Riau,

${ }^{8}$ Sutan Remi Sjahdeini, Good Governance :Antara Idealisme dan Kenyataan, Citra Aditya Bakti: Bandung, 2003.Page 3

${ }^{9}$ Robert B. Denhardt and Janet V. Denhardt, 2009. Public Administration: An Action Orientation, Wadsworth, Boston, Pages. 43-44
} 
parties, in the sense that the information released by the company is same and equitable for all parties concerned. Thus, it can be understood that the disclosure of information for the company will be largely determined by the quality of information presented to the stakeholders of the company itself. If the company deliversinformation is not maximal and it can be interpreted as a form of action that covers up the actual state or condition of the company, so contrary to the principle of transparency. The basic principle of transparency in the limited company is due to the interests of others in the company, so the transparency of information presented by the company is addressed to the parties concerned. Information disclosures are based on the provisions of the law and standards of decency prevailing in the world of business or company. ${ }^{10}$ In this context, the status of a Limited Company is a separate legal entity, which can bind and conduct legal activities. A Limited Company was established with act of notary and subsequently submitted to the Minister of Justice for legality. Once approved, the founder of the Limited Company is obligated to register the establishment of company in local courts. The founders of company are also obliged to announce the certificate of incorporation in the State Gazette.

Despite legalization from the Minister of Justice has not obtained, but a Limited Company has been able to operate its activities. Certificate of incorporation contains article of associationincludes intent, purpose and period of the establishment of Limited Company, the amount of basic capital, number of shares and its nominal value. In addition,certificate of incorporation is also contains about the authority and responsibilities of the board including the commissioner, annual accounts, the general meeting of shareholders, profit sharing, changes in the article of association and the changes of the Limited Company.

In essence, the application of the principle of transparency in the limited company meant that any interested party can obtain the correct information related to the activities of the company. ${ }^{11}$ It is intended to protect the public or the interested parties with the company so not to suffer losses due to have taken action based on the information that is not correct. ${ }^{12}$ Thus, it can be understood that the application of the principle of transparency is essentially a form of protection to stakeholders or all parties interested in the company.

The basic motivation that underlies the application of the principles of transparency for companies is different depending on the status of the company. Transparency of the limited company is basically based on the awareness of the company to implement the principles of Good Corporate Governance(GCG). One of the principles of Good Corporate Governance is transparency which requires companies to open or transparent in exercise its activities including providing company information to the parties concerned.

Transparency relates to the quality of information that submitted by the company. Investors' confidence is highly dependent on the quality of the information. Therefore, companies are required to provide information that is clear, accurate, and timely. Submission of information to the public in an open, correct, credible and timely will make it easier to assess the performance and risks faced by the company. The principle of transparency is the basis so that the aspect of disclosure becomes an indicator to assess the extent to which the company has been implementing Good Corporate Governance(GCG).

Disclosure is related to the accuracy and timeliness of the company to disclose its financial position, condition and prospects of the company, non-financial information, and easy access to information. Some practices developed in the context of transparency includes the companies required to disclose important transactions related to the companies, the risks faced and the plan/policy of the company (corporate actions) to be executed. In addition, companies also need to convey to all the company ownership structure and the changes that occur.

As described above, it is understood that a basis that can be used to determine the level of transparency or disclosure to a limited liability company, namely by looking at the extent to which the company has been implementing the principles of Good Corporate Governance(GCG). The better of GCG in its implementation, the better of disclosure level.

Generally,Good Corporate Governance (GCG) is required to maintain the survival of the company through a management system based on the principles of transparency, accountability, responsibility, independence and fairness. As a commitment of company in implementing GCG, some companies have formed a GCGs' Committee, which is one of the Committee established by the Commissioner. In outline, the task of this committee is to gives recommendations to the Commissioner regarding the policy and accelerating programs of the implementation of GCG and oversee the effective implementation of GCG by the Board of Directors and staff so that the stakeholders' interests can be protected and the creation of a mechanism of checks and balances on all activities.

\footnotetext{
${ }^{10}$ Muhammad Miqdad. Loc.Cit.

${ }^{11}$ William N. Dunn, 2000. Pengantar Analisis Kebijakan Publik, Gajah Mada University Press, Yogyakarta, Page. 117

${ }^{12}$ Hernoko, A., Anand, G., \& Raden Roro, F. (2017). Method Determining the Contents of the Contract. Hasanuddin Law Review, 3(1), 91-103. doi:http://dx.doi.org/10.20956/halrev.v3i1.947 
If reviewed from the aspect of substance or material charge, then the type of information released by the limited company can be divided into 2 (two)types that is financial information and non-financial information. The division of financial information type as shown in the table below.

Table 1. Types of financial information that can be disclosed by the company to related parties

\begin{tabular}{|c|l|c|c|c|c|c|}
\hline \multirow{2}{*}{ No } & \multirow{2}{*}{ Types of Information } & \multicolumn{5}{|c|}{ Disclosed for } \\
\cline { 3 - 7 } & & $\begin{array}{c}\text { Shareholde } \\
\mathrm{r}\end{array}$ & $\begin{array}{c}\text { Commissio } \\
\text { ner }\end{array}$ & $\begin{array}{c}\text { Director } \\
\text { Employ } \\
\text { ee }\end{array}$ & $\begin{array}{c}\text { Credit } \\
\text { or }\end{array}$ \\
\hline 1 & End-year balance & $\sqrt{ }$ & $\sqrt{ }$ & $\sqrt{ }$ & - & - \\
\hline 2 & Income report & $\sqrt{ }$ & $\sqrt{ }$ & $\sqrt{ }$ & - & - \\
\hline 3 & Cash flow report & $\sqrt{ }$ & $\sqrt{ }$ & $\sqrt{ }$ & - & - \\
\hline 4 & Equity report & $\sqrt{ }$ & $\sqrt{ }$ & $\sqrt{ }$ & - & - \\
\hline 5 & $\begin{array}{l}\text { Record of financial } \\
\text { statement }\end{array}$ & $\sqrt{ }$ & $\sqrt{ }$ & $\sqrt{ }$ & - & - \\
\hline
\end{tabular}

Source: Act 40 of 2007 on Limited Companies, 2016 (edited).

It appears that the information contained in the financial statements only disclose for shareholders, board of commissioners and directors. However, when companies make merger, consolidation, acquisition or separation of the company, the financial statements are also disclosed for employees and creditors.

\section{RESPONSIBILITIES OF DIRECTORS IN IMPLEMENTING THE PRINCIPLE OF TRANSPARENCY}

The Board of directors is an organ that plays an important role in determining the progress of a company or not. Legally, the importance of the position of directors drawn from the duties and responsibilities attached to it. The duties and responsibilities of directors as an organ is a collegial responsibility among members of the board of directors of the company. This means that any action taken or carried out by one or more members of the board of directors will be binding on the other board members. That does not mean the prohibition occurs division of tasks among members of the board of directors. Directors are fully responsible for the management of the company. Directors must comply with the company's statutes and regulations in force. In this case the board of directors must carry out their duties in good faith and responsibly. If a member of the board of directors found guilty or negligent in performing their duties, then the question will be held personally responsible.

The responsibilities of the directors in accordance with Article 97 paragraph (1), (2) and (3) of Limited Company Acts No. 40 of 2007 are:

(1) The Board of directors is responsible for managing the company for the sake of the company and in accordance with the purposes and objectives of the company.

(2) Management of the company by any member of the board of directors shall be implemented in good faith and responsibly.

(3) Each member of the board of directors is responsible personally for any losses if the relevant company at fault or negligent performing their duties.

Based on description above, it is understood that the directors in carrying out their duties must pay attention to the interests of the company, in accordance with the purposes and objectives of the company, and the provisions on the prohibition and restrictions provided in the Limited Company Acts and the articles of association. Furthermore, regarding the responsibility of directors in associated to the implementation of the principles of Good Corporate Governance (GCG).

\subsection{Responsibilities related to the transparency}

As a form of responsibility of the directors in applying the principle of transparency, the directors are fully responsible for the correctness and accuracy of all data and information made available to the public and the shareholders or third parties under the agreement, namely to matters relating to the financial performance, liability, shareholding and the issue of corporate governance.

The principle of transparency emphasize that disclosure should be applied in every aspect of the company relating to the public interest or the shareholders. Transparency in Good Corporate Governance is a form of open company management, disclosure of the facts is done accurately and on time to the stakeholders.

\subsection{Responsibilities related to the fairness}

The principle of fairness is to give equal treatment of shareholders. The same treatment is, for example in terms of providing true and accurate information on the company' performance, and this information is not 
given to certain shareholders, but all shareholders have equal opportunity to access the information needed. This is in accordance with the provisions of Article 75 paragraph (2) of Act 40 of 2007 which states that in the forum of General Meeting of Shareholder, shareholders are entitled to obtain information relating to the Company' Board of Directors and/or Board of Commissioners, as long related to the agenda item and not contradictory with the interests of the company.Other provisions as based on the principles of fairness stated that all shares issued for the capital increase must before be offered to each shareholder, balanced with shares ownership for the same class of shares. Including as a form of application of the principle of fairness is to give fair treatment and legal protection for minority shareholders, as well as prohibit the distribution of shares to the parties themselves and their trading by insiders. Provisions of those articles reflects the protection of shareholder rights and fair treatment for choose members of the board of directors, as well as the rights of shareholders to determine the amount and type of income of members of the board of directors.

\subsection{Responsibilities related to the accountability}

The principle of accountability is an embodiment of the obligation to account for the success or failure of the implementation of the vision and mission of the company, to achieve the goals and objectives that have been set. In other words, accountability is a periodic accountability of the board of the company. This principle is embodied among others by preparing financial statements in a timely and fast manner.The principle of accountability can be seen from the provisions of Article 97 of the Limited Company Act that directors are responsible for the management of the company and the management must be implemented by each member of the board of directors in good faith and responsibly. Then, in Article 100 of the Limited Company Acts governing the liability of directors to create and maintain a list of shareholders, the report of general meeting of shareholder, and meeting report of director, so the situation of the company can be seen at any time by the commissioners and shareholders.

\subsection{Responsibilities related to the responsibility}

The principle of responsibility is a principle relating to the responsibility of the directors and shareholders in a company, among others related to the fulfillment of corporate social responsibility as part of the community. Companies must support the law supremacy, must follow the rules in the field of taxation, labor and occupational safety, health, environment, consumer protection and prohibition of monopolistic practices and unfair business competition.

Responsibilities of directors relating to the principle of responsible that board of directors are responsible for all legal actions undertaken by the company during the company has not become legal entity as the responsibility of the board of directors, founders and board of commissioners as contained in Article 14 of the Limited Company Act. Make annual report for responsibility of the company. The Board of Directors shall in good faith and responsibly carry out duties in the interests and objectives of the company.Basically, responsibility of the directors in the implementation of the principle of transparency is concerned with the information that must be disclosed or published by the company to the parties concerned. Information disclosures are based on the provisions of the law and standards of decency prevailing in the world of business or company.Research results as conducted at PT. Charoen Pokphand Indonesia, obtained information about the types of information provided by the company as shown in the following table.

Table 2. Types of available reports by corporate policy PT.Charoen Pokphand Indonesia

\begin{tabular}{|c|l|c|c|}
\hline No & \multicolumn{1}{|c|}{ Types of Report } & \multicolumn{1}{|c|}{ Available } & \multicolumn{1}{c|}{$\begin{array}{c}\text { Not } \\
\text { Available }\end{array}$} \\
\hline 1 & Company profile & $\sqrt{ }$ & - \\
\hline 2 & Annual report & $\sqrt{ }$ & - \\
\hline 3 & Financial statement & $\sqrt{ }$ & - \\
\hline 4 & Balance of income & $\sqrt{ }$ & - \\
\hline 5 & Cash flow statement & $\sqrt{ }$ & - \\
\hline 6 & List of asset and investment & - & $\sqrt{ }$ \\
\hline 7 & List of equity & $\sqrt{ }$ & - \\
\hline 8 & Assessment report of GCG & - & $\sqrt{ }$ \\
\hline 9 & Report of corporate performance: & - & $\sqrt{ }$ \\
\hline & - Administration & - & $\sqrt{ }$ \\
\hline & - Finance & $\sqrt{ }$ & - \\
\hline & - Operational & $\sqrt{ }$ & - \\
\hline 10 & Summary information on programs and/or activities by the \\
& company & & \\
\hline 11 & Reports on corporate social responsibility & & \\
\hline
\end{tabular}


\begin{tabular}{|l|l|l|l|}
\hline 12 & Report of information access by the public & $\sqrt{ }$ & - \\
\hline
\end{tabular} Source: Proceed data, 2016

Generally, the information provided by the limited company is only intended for the benefit of the internal stakeholders like shareholders, commissioners and directors including employees of the company. As table above, it appears that some type of information has not been provided by the company to be accessed by the public. Among other types of information about the list of equity, report of corporate performance, assessment report of corporate governance, corporate performance of administrative, financial and operational.

Furthermore, the provision set forth in Act 40 of 2007 has not been implemented properly. Under these provisions is determined that the information should be published by the company include corporate activities, information about assets and investments as well as capital. Thus it can be understood that the application of the principle of disclosure in the limited company still needs to be further enhanced.

Relating to the information material as presented by the company, it can generally be viewed from two aspects of information material and recipient. The more complete material presentedand the wider range of information recipient disclosed by the company, the level of disclosure is also higher.

The results showed that although the company stated that the information the company is always available to stakeholders and can be accessed at any time, but there is no section or department of company to handle its work specifically the availability of information for the parties concerned. In addition, the company also has not been present the entire company information and its management analysis on the Internet or other mass media which is easily accessible by the public. This suggests that the dominant of company information can only be accessed by the company's internal stakeholders like shareholders, commissioners, directors and employees.

The company also has internal auditor and has audited also by an independent auditor. This indicates that the information disclosed by the company has been objective and can be accounted for in accordance with auditing standards applicable to the company. Therefore, it becomes necessity for the company to be audited by both internal and external auditors. This meant that the public trust for the company can be more assured.

One of the factors that become cause for a report on the implementation of social and environmental responsibility is not contained in the annual report of the company because under the terms of Article 74 of Act 40 of 2007, that the implementation of social and environmental responsibility is not required for all of the company. The companies are obliged to carry out social and environmental responsibility is only intended for companies running business in the field and/or related to natural resources. PT. Charoen Pokphand Indonesia is engaged in the field of animal feed, so that it is understood that the company is not conducting its business activities in the field and/or are directly related to the natural resources management.

Generally, the responsibilities of directors in the application of the principle of disclosure in the limited company are addressed both to the internal and external stakeholders of the company. However, the nature of disclosure is limited to certain material as contained in the annual report of the company. In accordance with the provisions of Article 29 paragraph (5) of Act 40 of 2007, that the information contained in the list of companiessuch as company profile, performance report and other reports related to corporate finance such as balance sheet and income statement, as information that can be accessed by the public. While, the information contained in the annual reports of limited company is addressed to the shareholders and other internal stakeholders such as commissioners and directors themselves.

\section{IRGENCY THE PRINCIPLE OF TRANSPARENCY IN REALIZE GOOD CORPORATE GOVERNANCE}

The principle of transparency is an important principle to prevent the fraud. ${ }^{13}$ By provides information under the principle of transparency, it can be anticipated the possibility of losses for shareholder, investors or stakeholder, beside because no information or material facts relating to the company in uniform and equitable for all parties. The application of the principle of transparency in the limited company allows for auditing or assessment to the implementation of the principles of Good Corporate Governance as fairness, accountability, and responsibility. So it can be understood that the principle of transparency/disclosure is one of the most important principles in Good Corporate Governance.

The principle of transparency emphasized that information should be disclosed in a timely and accurate. Information disclosed includes financial performance, operating, ownership and company management as well as other information that are both financial and non-financial information. ${ }^{14}$ Audits conducted on such information should be made independently. Disclosure or transparency is required so that the trust of

\footnotetext{
${ }^{13}$ NdaruningpuriWulandari, 2006. PengaruhIndikatorMekanismeCorporate GovernanceTerhadapKinerjaPerusahaan PublikdiIndonesia. Jurnal Fokus Ekonomi, 1(2): 17

${ }^{14}$ Smith, Rex Deighton. 2004. Regulatory Transparency in OECD Countries: Overview, Trends a,d Challenges. Australian Journal of Public Administration, 14(2): 52-79 
shareholders and other related parties can be increased. Without the principle of transparency, then any information released by the company is difficult to believe both in the truth and accuracy.Delivery of information can be done through brochures, banners, television, print media, electronic media, and radio. It is allowed as long as no violation. While, information from the superior to subordinates is given in a briefing and other meetings as well as through pamphlets attached on the bulletin board.For a public company or open company are required to maintain objectivity in conducting its business activities by providing relevant information material to the shareholders and other stakeholders. The company must also ensure the availability of information that is timely, appropriate, clear, accurate, and easily accessible.Delivering various routine reports that become a necessity for the public company include interim financial statements, semester financial statements, audit annual financial statements, annual reports, and incidental reports which included matters related to the corporation action, affiliate transaction, or material transaction. All in the form of public exposure and mass media. In addition, the company must provide the official website as one of the means that can be accessed by general public to obtain information about the annual report of the company.Information disclosure about material facts are accurately and fully for the open company is expected to realize the purpose of the principle of transparency and anticipate misleading statement for investors or other interested parties.

As research result that has been conducted, the findings obtained with regard to the information disclosure on limited companies, both on theoretical and practical aspects. First, theoretically, the applicationof the principle of transparency on the closed Limited Company or not go public, basically it is only voluntary, and applied as part of Good Corporate Governance (GCG). Its purpose is to increase public confidence or external stakeholders. While, the application of the principle of transparency on publicly listed company is basically to provide protection to shareholders and other external stakeholders to avoid a wide variety of corporate actions which can result in losses. The application of the principle of transparency in open company is a form of financial obligations, according to the legislation in force.Secondly, practically has developed a simple questionnaire in the form of a self-assessment check list that can be used independently by the company to assess the level of transparency and quality of the information presented by the company to the public or to other related parties. The simple questionnaire can be developed by adding indicators, as well as the types of material were assessed. The more complete and more specifically the materials assessed it will be increasingly depict reality or the real condition of the company. In addition, the weighting of each indicator can also be changed, depending on which indicators are considered the most determining the level of transparency of the company. The result of questionnaire assessment quality will be highly dependent on the knowledge, experience, and objectivity of the parties who are responsible for filling out the questionnaire.

\section{CONCLUSION}

The basic concepts of transparency werean attitude or action of the company to disclose entire business and information material about the effects that can affect the decisions of investors or other stakeholders. Information disclosure is determined by 3 (three) factors: clear, accurate, and timely. These third determines the quality of information presented by the company. In applying the principles of transparency, the board of directors is responsible for providing information to stakeholders both internal and external. The application of the principle of transparency in the limited company or SOEs that has not go publicas voluntary as part of the application of the principles of Good Corporate Governance, while the open company, the application of the principles of transparency is an obligation which is accompanied by sanctions. The application of the principle of transparency in the limited company shows that the level of transparency tends to be higher in term of nonfinancial information, but instead tend to be closed when it comes to financial information, particularly on the closed company or not a public company. However, the quality of the providing of non-financial information tends to be lower compared with financial information. Most of the material of non-financial information is less regularly updated. Based on the result of research, the researchers suggest that the company may have the special department that handles each request for information coming into the company, so that other interested parties with company information can be served well.

\section{REFERENCES}

[1] Erwin Fajrin Hadat, Informasi: Kebutuhan yang Terabaikan, Buletin BUMN, 65(4): 28.

[2] Hernoko, A., Anand, G., \& Raden Roro, F. (2017). Method Determining the Contents of the Contract. Hasanuddin Law Review, 3(1), 91-103. doi:http://dx.doi.org/10.20956/halrev.v3i1.947

[3] KPK, Studi Implementasi Good Corporate Governance di Sektor Swasta, BUMN dan BUMD. KPK, Direktorat Penelitian dan Pengembangan, Jakarta, 2007.

[4] Luhgiatno. 2008. Mencegah Tindakan Manajemen Laba dengan Mekanisme Corporate Governance, Jurnal Fokus Ekonomi, 3(2): 32-43. 
[5] Muhammad Miqdad, 2012. Praktik Tatakelola Perusahaan (Corporate Governance). Jurnal Manajemen dan Kewirausahaan, 14(2): 9.

[6] NdaruningpuriWulandari,2006.PengaruhIndikatorMekanismeCorporateGovernanceTerhadapKinerjaPeru sahaan PublikdiIndonesia. Jurnal Fokus Ekonomi, 1(2): 17.

[7] Robert B. Denhardt and Janet V. Denhardt, 2009. Public Administration: An Action Orientation, Wadsworth, Boston.

[8] Smith, Rex Deighton. 2004. Regulatory Transparency in OECD Countries: Overview, Trends a,d Challenges. Australian Journal of Public Administration, 14(2): 52-79.

[9] Sutan Remi Sjahdeini, Good Governance :Antara Idealisme dan Kenyataan, Citra Aditya Bakti: Bandung, 2003.

[10] Tavinayati and Yulia Qamariyanti. 2009.Hukum Pasar Modal Indonesia, Jakarta: Sinar Grafika.

[11] William N. Dunn, 2000. Pengantar Analisis Kebijakan Publik, Gajah Mada University Press, Yogyakarta. 